\title{
Sipuleucel-T immunotherapy for castration-resistant prostate cancer. A systematic review and meta-analysis
}

Paweł Kawalec ${ }^{1}$, Anna Paszulewicz'2, Przemysław Holko ${ }^{3}$, Andrzej Pilc ${ }^{1,4}$

${ }^{1}$ Drug Management Department, Institute of Public Health, Faculty of Health Sciences, Jagiellonian University, Krakow, Poland

2Division of Cell Biophysics, Faculty of Biochemistry, Biophysics and Biotechnology, Jagiellonian University, Krakow, Poland

3Department of General Biochemistry, Faculty of Biochemistry, Biophysics and Biotechnology, Jagiellonian University, Krakow, Poland

${ }^{4}$ Department of Neurobiology, Institute of Pharmacology, Polish Academy of Sciences, Krakow, Poland

Submitted: 8 March 2012

Accepted: 23 July 2012

Arch Med Sci 2012; 8, 5: 767-775

DOI: 10.5114/aoms.2012.31610

Copyright () 2012 Termedia \& Banach

\section{Abstract}

Introduction: Sipuleucel-T is a novel active cellular immunotherapy for the treatment of asymptomatic or minimally symptomatic metastatic castrate-resistant prostate cancer (mCRPC). It is assumed to be associated with less adverse events than conventional docetaxel-based chemotherapy.

Material and methods: A systematic review of literature published between January, 11966 and February, 62012 was performed to assess the efficacy and safety of sipuleucel-T in patients with MCRPC. Databases were searched: Medline, EMBASE, Cochrane, CancerLit as well as ASCO and ESCO websites.

Results: Three randomized clinical trials with a total of 737 participants fulfilled established criteria. The overall survival of patients who received sipuleucel-T in comparison to the control group was significantly longer with a hazard ratio $(\mathrm{HR})$ of 0.73 (95\% Cl: $0.61-0.88 ; p=0.001)$. Time to disease progression was not prolonged using sipuleucel-T compared to placebo, $\mathrm{HR}=0.89$ (95\% Cl: 0.75-1.05; $p=0.18$ ). Relative benefit (RB) of serum PSA level reduction of at least $50 \%$ for sipuleucel-T compared to placebo did not meet statistical significance, RB $=1.97$ (95\% Cl: $0.48-8.14 ; p=0.38)$. The safety population consisted of 729 patients with $\mathrm{mCRPC}$. Compared to the control group, the pooled relative risks (RR) of all adverse events $-\mathrm{RR}=1.03(95 \% \mathrm{Cl}: 1.00-1.05 ; p=0.06)$, grade 3 to 5 adverse events $-\mathrm{RR}=0.98(95 \% \mathrm{Cl}: 0.79-1.22 ; p=0.86)$ and cerebrovascular events $\mathrm{RR}=1.93(95 \% \mathrm{Cl}: 0.73-5.09 ; p=0.18)$ were not significantly higher for men treated with sipuleucel-T.

Conclusions: The use of sipuleucel-T prolonged the overall survival among men with $\mathrm{mCRPC}$. No effect on time to disease progression was observed and the safety profile was acceptable.

Key words: APC 8015, prostate cancer vaccine, sipuleucel-T, Provenge.

\section{Introduction}

Prostate cancer is one of the most common malignant forms of cancer among men [1]. Between 2005 and 2009 there were about 7,900 new cases of the disease among Polish patients and the standardized incidence ratio for 2009 was 32.8. There were also around 3900 deaths due to

\author{
Corresponding author: \\ Paweł Kawalec PhD \\ Drug Management \\ Department \\ Institute of Public Health \\ Faculty of Health Sciences \\ Jagiellonian University \\ 20 Grzegorzecka St \\ 31-531 Krakow, Poland \\ Phone: +48124241390 \\ Fax: +48 124217447 \\ E-mail: \\ pawel.kawalec@uj.edu.pl
}


prostate cancer each year and the standardized mortality rate for 2009 was 13.1 [2]. Low level of oncological awareness (i.e. screening tests used for the early detection of prostate cancer) results in late diagnosis and poor outcome [3].

Localized prostate cancer may be cured with surgery or radiation therapy, but the disease recurs in approximately $19 \%$ to $32 \%$ of patients [4-8]. Androgen-deprivation therapy, the most common treatment after recurrence, is effective; however, the disease eventually progresses in most men who receive such treatment [9]. Management of this castration-resistant state, also known as androgenindependent prostate cancer (AIPC), is a significant clinical challenge. It remains an incurable disease, given the availability of treatment options that modestly extend survival by a median of 2 to 4 months. Docetaxel-based regimens have been acknowledged as the standard first-line chemotherapy [10], but are associated with serious adverse effects (i.e., grade 3 or 4 neutropenia, infection, anemia, neuropathy) [11]. New treatments with fewer side effects are needed [12, 13].

Sipuleucel-T is an active cellular immunotherapy, a type of therapeutic cancer vaccine, consisting of autologous peripheral-blood mononuclear cells (PBMCs), including antigen-presenting cells (APCs) that have been activated ex vivo with a recombinant fusion protein (PA2024). This protein consists of a prostate antigen, prostatic acid phosphate, that is fused to a granulocyte-macrophage colony-stimulating factor: an immune-cell activator [13]. On April 29, 2010, the Food and Drug Administration (FDA) approved the drug sipuleucel-T (PROVENGE ${ }^{\circledR}$, made by the Dendreon Corporation) for the treatment of asymptomatic or minimally symptomatic metastatic castrate-resistant (hormone refractory) prostate cancer [14].

The aim of this review was to identify all of the randomized controlled trials comparing sipuleucel-T to placebo for men with MCRPC and to provide reliable evidence on the efficacy and safety of the novel therapy.

\section{Material and methods}

\section{Data sources and searches}

The study was conducted according to the preferred reporting items for systematic reviews and meta-analyses (PRISMA) guidelines [15]. A systematic search of electronic databases, abstract proceedings of major scientific meetings, and bibliographies of all eligible studies published between January 1, 1966 and February 6, 2012 was conducted to identify all of the relevant studies. Databases searched included Medline (PubMed), Embase, Cochrane Registry of Controlled Trials (CENTRAL) and, additionally, the ISI Web of Science, Scopus,
CancerLit, American Society of Clinical Oncology (ASCO), and European Society of Medical Oncology (ESMO).

The search strategy involved the following terms combined with Boole's logical operators [16]: ("sipuleucel" OR "sipuleucel T" OR "sipuleucel-T" OR "APC-8015" OR "APC8015" OR "APC 8015" OR "Provenge" OR "PA024 Antigen") for intervention AND ("prostate cancer*" OR "prostatic neoplasm*" OR "prostate neoplasm*" OR "cancer of the prostate" OR "cancer of prostate" OR "prostatic cancer*" OR "prostate gland cancer") for population. The search results were restricted to humans and methodological filters were used to identify clinical trials and randomized clinical trials. Studies were considered irrespective of language or publication status.

\section{Study selection}

Randomized controlled trials investigating the effectiveness of sipuleucel-T for men with metastatic castration-resistant prostate cancer were eligible for inclusion. Although all of the relevant records were identified and included in the systematic review, the meta-analysis was based on full-text articles only.

\section{Data extraction and quality assessment}

A coherent form was created, piloted, and then used to abstract the available data for the predefined outcomes of interest. These were: overall survival (OS), time to progression (TTP), probability of at least $50 \%$ reduction of the PSA level, adverse events of any grade, and adverse events grades 3 to 5. Two authors extracted data independently. Disagreements were resolved by discussion, consensus, and arbitration by a third author.

The Jadad score, which evaluates studies based on their description of randomization, blinding, and dropouts (withdrawals), was used to assess the methodological quality of the trials [17]. The quality scale ranges from 0 to 5 points with a low-quality report for a score of 2 or less and a high-quality report for a score of at least 3.

\section{Data synthesis and analysis}

Relative benefit (RB) or relative risk (RR) and 95\% confidence intervals $(95 \% \mathrm{Cl})$ were used to summarize the probability of at least a $50 \%$ reduction of the PSA level and adverse events. Hazard ratios $(\mathrm{HR})$ and $95 \% \mathrm{Cl}$ were used for overall survival (OS) and time to progression (TTP). The median "timeto-event" data and range were also presented for OS and TTP.

Relative benefits were calculated as the proportion of occurrence frequency for the particular outcome between the two treatment arms and their 95\% confidence intervals were calculated using the 
$\chi^{2}$ test. The hazard ratios with the confidence intervals were acquired from original papers according to their authors. As the approach to calculating these statistics may have varied across the studies, an effort was made to extract the parameter from all of the studies calculated with the unadjusted Cox regression model. Due to the inconsistency in presenting hazard ratio values (the HR defined as the risk in patients treated with a placebo divided by the risk for patients treated with sipuleucel-T), it was necessary to calculate the inverse value in such instances.

The results obtained from separate trials were combined using appropriate meta-analysis methods. The inverse variance, Mantel-Haenszel or Der Simonian-Laird effects model, was used according to the data input and heterogeneity test results.

The clinical heterogeneity was assessed by examining characteristics of the featured studies, whereas the statistical heterogeneity was detected using formal testing with Cochrane $Q$ and the inconsistency level $R^{2}$ [16]. The possibility of publication bias was not assessed due to the very limited number of studies included [18]. Meta-analysis was performed with RevMan ${ }^{\circledR} \mathrm{V} 5.1$. (The Nordic Cochrane Centre Software, Copenhagen) [19], and the relevant calculations were made using Microsoft Office Excel $2007^{\circledR}$ (Microsoft ${ }^{\circledR}$ Corporation) [20].

Due to the limited data available, the metaanalysis was not carried out in subgroups and only the results for the general population were presented.

\section{Results}

\section{Systematic review}

The electronic searches yielded 548 items after duplicates were removed. Of these, 24 articles were fully scrutinized. Twelve of the studies were considered ineligible due to lack of randomization, use of combination therapy with another anti-cancer agent, review or systematic review, different population or irrelevant outcomes. Twelve articles and conference abstracts met the predefined inclusion criteria [21-32]. The flow of information through the different phases of the systematic review is shown in Figure 1.

The studies included in the meta-analysis comprised full texts of 3 randomized clinical trials (RCTs): D9901 trial [21], the D9902A trial published together with data from the D9901 trial [25], and the IMPACT (Immunotherapy for Prostate Adenocarcinoma Treatment) study [26]. A total of 737 participants were randomized, with 488 patients having taken sipuleucel-T and 249 patients having taken a placebo. All of the studies were homogeneous with regard to the patients' age, diagnosis, basic biochemical parameters, and methodological aspects, e.g. Jadad score (Table I).

\section{Quantitative assessment - efficacy}

The assessed efficacy of sipuleucel-T versus the placebo comprises results for the following clinically important outcomes: HR for overall survival, HR for time to disease progression, median survival

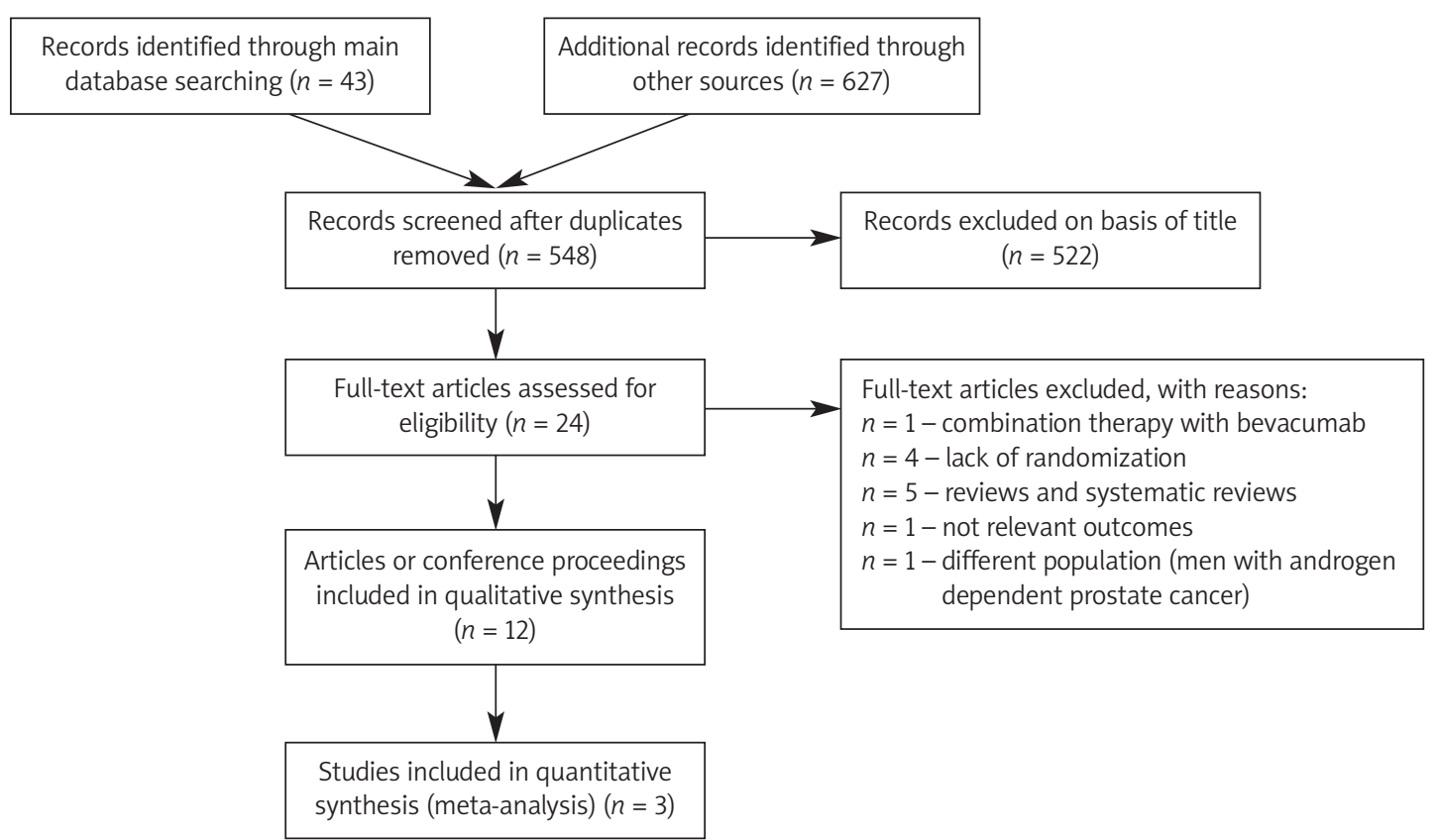

Figure 1. PRISMA flow diagram for the database search for sipuleucel-T vs. placebo for treatment of castration-resistant prostate cancer (CRPC) 
Table I. Characteristics and methodological quality of the randomized controlled trials for sipuleucel-T compared to placebo for castration-resistant prostate cancer

\begin{tabular}{|c|c|c|c|c|}
\hline Parameter & & $\begin{array}{c}\text { D9901 } \\
\text { (Small et al. 2006) [21] }\end{array}$ & $\begin{array}{c}\text { D9902A } \\
\text { (Higano et al. 2009) [25] }\end{array}$ & $\begin{array}{c}\text { IMPACT } \\
\text { (Kantoff et al. 2010) [26] }\end{array}$ \\
\hline \multirow{2}{*}{$\begin{array}{l}\text { Number } \\
\text { of participants } \\
\text { in study group }\end{array}$} & Sipuleucel- & 82 & 65 & 341 \\
\hline & Placebo & 45 & 33 & 171 \\
\hline $\begin{array}{l}\text { Median age } \\
\text { of participants }\end{array}$ & & Approx. 72 years (47-86) & Approx. 71 years (51-87) & Approx. 70 years (40-91) \\
\hline $\begin{array}{l}\text { Diagnosis and } \\
\text { eligibility criteria }\end{array}$ & & $\begin{array}{l}\text { Men with asymptomatic } \\
\text { metastatic hormone refractory } \\
\text { prostate cancer (HRPC); } \\
\text { expected survival } \\
\text { of at least } 3 \text { months }\end{array}$ & $\begin{array}{c}\text { Men with asymptomatic } \\
\text { metastatic hormone refractory } \\
\text { prostate cancer (HRPC); } \\
\text { expected survival } \\
\text { of at least } 3 \text { months }\end{array}$ & $\begin{array}{l}\text { Men with metastatic } \\
\text { castration-resistant } \\
\text { prostate cancer; } \\
\text { expected survival } \\
\text { of at least } 6 \text { months; } \\
\text { any Gleason score; } \\
\text { patients with } \\
\text { asymptomatic } \\
\text { disease or minimally } \\
\text { symptomatic }\end{array}$ \\
\hline $\begin{array}{l}\text { Median serum } \\
\text { prostate specific } \\
\text { antigen (PSA) } \\
\text { level (range) }\end{array}$ & & $\begin{array}{l}\text { Approx. } 47 \mathrm{ng} / \mathrm{ml} \\
(3.5-3621.0 \mathrm{ng} / \mathrm{ml})\end{array}$ & $\begin{array}{l}\text { Approx. } 50 \mathrm{ng} / \mathrm{ml} \\
(8.0-1342.0 \mathrm{ng} / \mathrm{ml})\end{array}$ & $\begin{array}{l}>5 \mathrm{ng} / \mathrm{ml} ; \\
\text { approx. } 50.0 \mathrm{ng} / \mathrm{ml}\end{array}$ \\
\hline $\begin{array}{l}\text { Serum } \\
\text { testosterone } \\
\text { level }\end{array}$ & & $<50 \mathrm{ng} / \mathrm{dl}(<17 \mathrm{nmol} / \mathrm{l})$ & $<50 \mathrm{ng} / \mathrm{dl}(<17 \mathrm{nmol} / \mathrm{l})$ & $<50 \mathrm{ng} / \mathrm{dl}(<17 \mathrm{nmol} / \mathrm{l})$ \\
\hline Design & & $\begin{array}{l}\text { Double-blind, randomized; } \\
\text { possibility to allocate } \\
\text { from placebo group } \\
\text { after disease progression }\end{array}$ & $\begin{array}{l}\text { Double-blind, randomized; } \\
\text { possibility to allocate } \\
\text { from placebo group } \\
\text { after disease progression }\end{array}$ & $\begin{array}{l}\text { Double-blind, randomized; } \\
\text { possibility to allocate } \\
\text { from placebo group } \\
\text { after disease progression }\end{array}$ \\
\hline Randomization & & $\begin{array}{l}2: 1 \text {; block randomization } \\
\text { stratified by: study center } \\
\text { and bisphosphonate use }\end{array}$ & $\begin{array}{l}2: 1 \text {; block randomization } \\
\text { stratified by: study center } \\
\text { and bisphosphonate use }\end{array}$ & $\begin{array}{l}2: 1 \text {; stratified by: } \\
\text { Gleason score, number } \\
\text { of bone metastases, } \\
\text { bisphosphonate use }\end{array}$ \\
\hline Jadad score & & 3 & 3 & 3 \\
\hline
\end{tabular}

Table II. Median time of overall survival and time to progression from individual trials for sipuleucel-T compared to placebo for castration-resistant prostate cancer

\begin{tabular}{|llccc|}
\hline Parameter & Group & $\begin{array}{c}\text { D9901 } \\
\text { (Small et al. 2006) [21] }\end{array}$ & $\begin{array}{c}\text { D9902A } \\
\text { (Higano et al. 2009) [25] }\end{array}$ & $\begin{array}{c}\text { IMPACT } \\
\text { (Kantoff } \text { et al. 2010) [26] }\end{array}$ \\
\hline $\begin{array}{l}\text { Median overall } \\
\text { survival [months] }\end{array}$ & Sipuleucel-T & $25.9(20.0-32.4)$ & $19.0(13.6-31.9)$ & 25.8 \\
\cline { 2 - 5 } & Placebo & $21.4(12.3-25.8)$ & $15.7(12.8-25.4)$ & 21.7 \\
\hline $\begin{array}{l}\text { Median time to } \\
\text { progression [weeks] }\end{array}$ & Sipuleucel-T & $11.7(9.1-16.6)$ & $10.9(9.3-17.7)$ & 14.6 \\
\cline { 2 - 5 } & Placebo & $9.1(8.7-13.1)$ & $9.9(8.4-18.0)$ & 14.4 \\
\hline
\end{tabular}

time, median time to disease progression, and at least a $50 \%$ reduction of the serum PSA level.

\section{Overall survival}

Three trials that included 737 randomized participants contributed the information on overall survival $[21,25,26]$. The median survival time was presented for each study separately for sipuleucel-T and the placebo group, and a meta-analysis of hazard ratios was performed. The median time of overall survival was 4.5 months longer in sipuleucel- $T$ than in the placebo group for patients in D9901 [21], 3.3 months longer in the D9902A trial [25], and 4.1 months longer in the IMPACT trial [26] (Table II). Because event rates for time intervals were not available in the studies, we used the inverse variance 
method to pool summary log hazard ratios from individual trials, confirming the strong positive influence of sipuleucel-T on the overall survival of men with castration-resistant prostate cancer (Figure 2, Table III). The survival effect with sipuleucel-T was observed despite the inclusion of optional APC8015F salvage therapy for placebo-treated patients.

\section{Time to progression}

Three trials that included 737 randomized participants contributed the information on time to progression (TTP) $[21,25,26]$. The median time to progression was presented for each study separately for the sipuleucel-T and placebo groups and a meta-analysis of hazard ratios was performed. The median TTP was 2.6 weeks longer in the sipuleucel-T group than in the placebo group for patients in D9901 [21], 1 week longer in the D9902A trial [25], and 0.2 weeks longer in the IMPACT trial [26] (Table II). Both the median time to disease progression and a meta-analysis of hazard ratios for this outcome indicate that a significant effect of sipuleucel-T on disease progression was not observed (Figure 3, Table III).

\section{Serum PSA level reduction of at least $50 \%$}

Data on reduction of the serum PSA level of at least $50 \%$ were available from one randomized control trial [26]. The analysis included 464 randomized participants for whom the post-baseline serum PSA level was assessed. Relative benefit (RB) was calculated but a statistical difference between treatment arms was not observed (Table III).

\section{Quantitative assessment - safety}

\section{All adverse events and adverse events grades 3 to 5}

The incidence of adverse events was available from three randomized control trials [21, 25, 26]. The analysis was based on a safety population (patients who underwent at least 1 leukapheresis) of 729 men with castration-resistant prostate cancer randomized to sipuleucel-T or placebo. The analyzed population consisted of an integrated safety population from D9901 and D9902A trials [25] consisting of 223 of 225 men, and a safety population from the IMPACT trial [26] that included 506 of 512 patients. The analysis included the overall incidence of adverse events, and the occurrence of adverse events with grades 3 to 5 (according to the National Cancer Institute's Common Toxicity Criteria version 2.0 [25] or 3.0 [26]). The pooled relative risk (RR) of occurrence of adverse events (Figure 4) and adverse events grades 3 to 5 (Figure 5) indicated lack of statistical difference between the therapy with sipuleucel-T and the placebo regarding those safety endpoints (Table III).

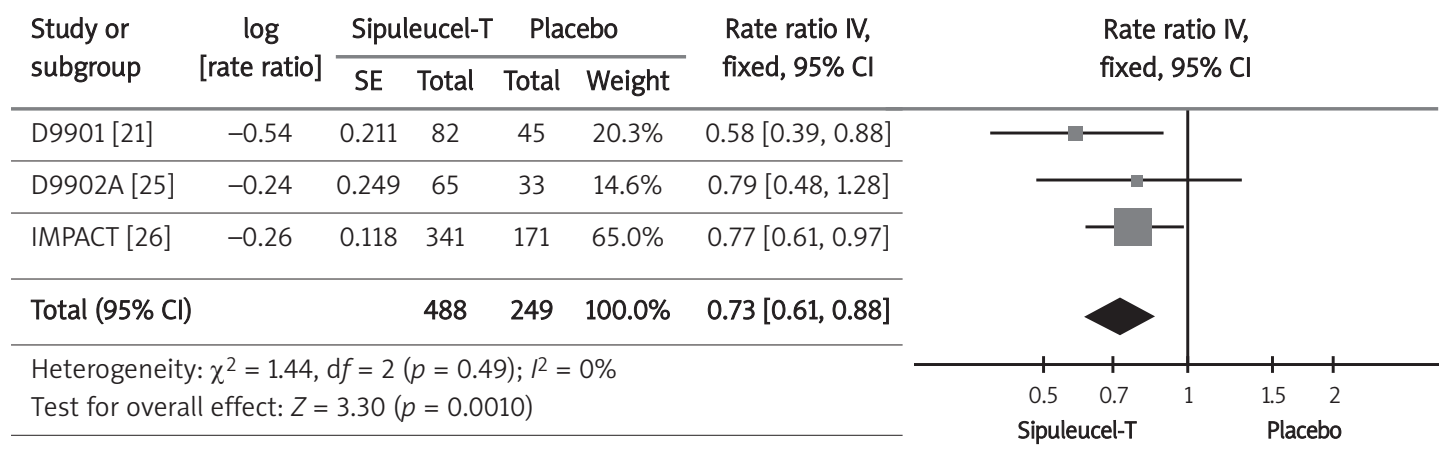

Figure 2. Forest plot representing the effects of therapy with sipuleucel-T and placebo use on hazard ratio of overall survival in men with CRPC

Table III. Efficacy and safety meta-analysis and single study results for sipuleucel-T compared to placebo for castration-resistant prostate cancer

\begin{tabular}{|c|c|c|c|}
\hline Parameter & References & Results & Value of $p$ \\
\hline Overall survival & \multirow{2}{*}{$\begin{array}{l}\text { Meta-analysis (D9901 [21], } \\
\text { D9902A [25], IMPACT [26]) }\end{array}$} & $\mathrm{HR}=0.73(95 \% \mathrm{Cl}: 0.61-0.88)$ & 0.001 \\
\hline Time to progression & & $\mathrm{HR}=0.89(95 \% \mathrm{Cl}: 0.75-1.05)$ & 0.17 \\
\hline Serum PSA level reduction of at least $50 \%$ & IMPACT [26] & $\mathrm{RB}=1.97(95 \% \mathrm{Cl}: 0.48-8.14)$ & 0.38 \\
\hline All adverse events & \multirow{2}{*}{$\begin{array}{l}\text { Meta-analysis (D9901 [21], } \\
\text { D9902A [25], IMPACT [26]) }\end{array}$} & $\mathrm{RR}=1.03(95 \% \mathrm{Cl}: 1.00-1.05)$ & 0.06 \\
\hline Adverse events grades 3 to 5 & & $\mathrm{RR}=0.98(95 \% \mathrm{Cl}: 0.79-1.22)$ & 0.86 \\
\hline Cerebrovascular events & $\begin{array}{l}\text { Meta-analysis (D9901 and } \\
\text { D9902A [25], IMPACT [26]) }\end{array}$ & $\mathrm{RR}=1.93(95 \% \mathrm{Cl}: 0.73-5.09)$ & 0.18 \\
\hline
\end{tabular}




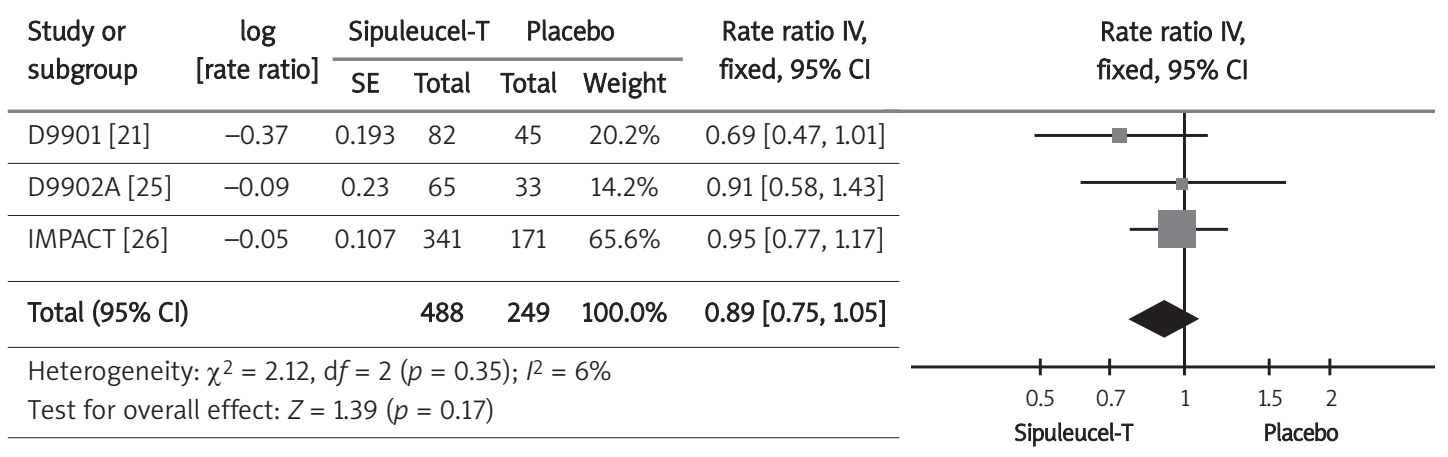

Figure 3. Forest plot representing effects of therapy with sipuleucel-T and placebo use on hazard ratio of time to progression in men with CRPC

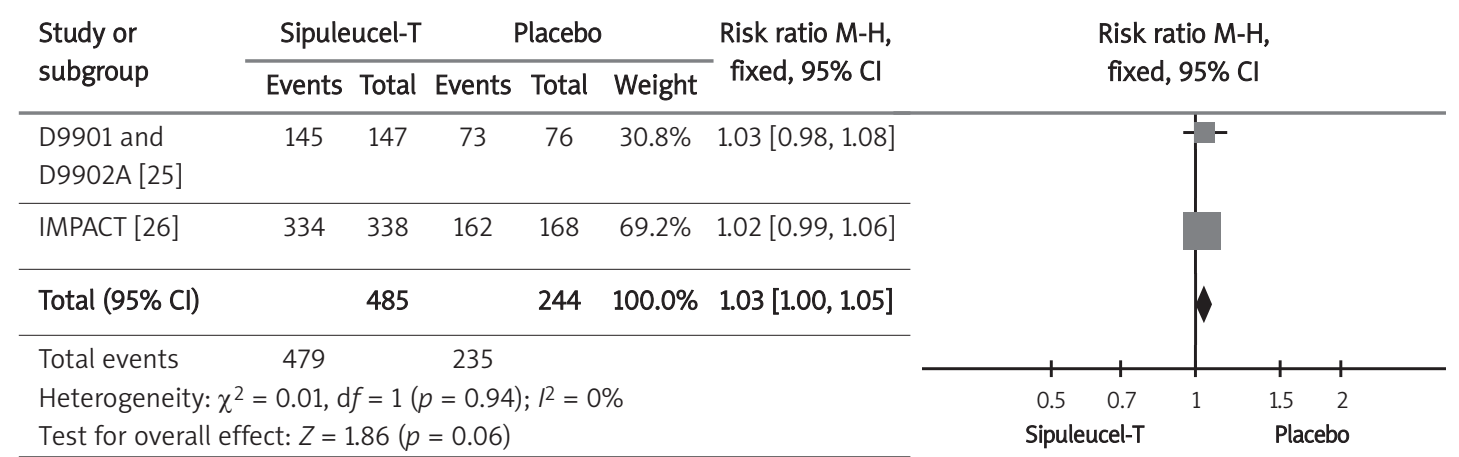

Figure 4. Forest plot representing effects of sipuleucel-T and placebo use on probability of incidence of all adverse events (any grade) in men with CRPC

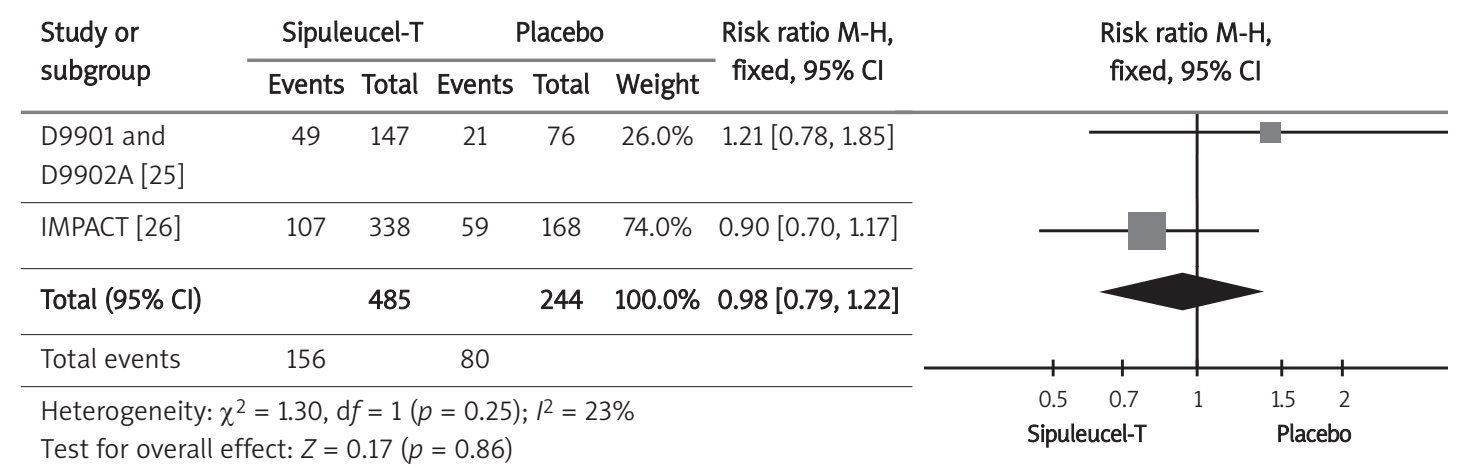

Figure 5. Forest plot representing effects of sipuleucel-T and placebo use on incidence of grade 3 to 5 adverse events in men with CRPC

\section{Cerebrovascular events}

The most serious adverse events possibly related to sipuleucel-T use were cerebrovascular events (e.g., hemorrhagic, ischemic, embolic, transient ischemic attack, and bleeding from a dural metastatic lesion). Data on the probability of cerebrovascular events were available from three randomized control trials: integrated data from the D9901 and D9902A trials [25] and the IMPACT trial [26]. The safety population included 729 randomized participants who underwent at least one leukapheresis. The meta-analysis results (Figure 6, Table III) did not confirm the influence of sipuleu-
cel-T on the increased risk of cerebrovascular events.

\section{Discussion}

All of the studies included in the meta-analysis are of good quality and are homogeneous with regard to their clinical aspects. Nevertheless, two of them (D9901 [21] and D9902A [25]) were designed to evaluate the time to disease progression (TTP) rather than overall survival as a primary endpoint.

The results of the meta-analysis in the present review confirm the findings reported by authors [21, 


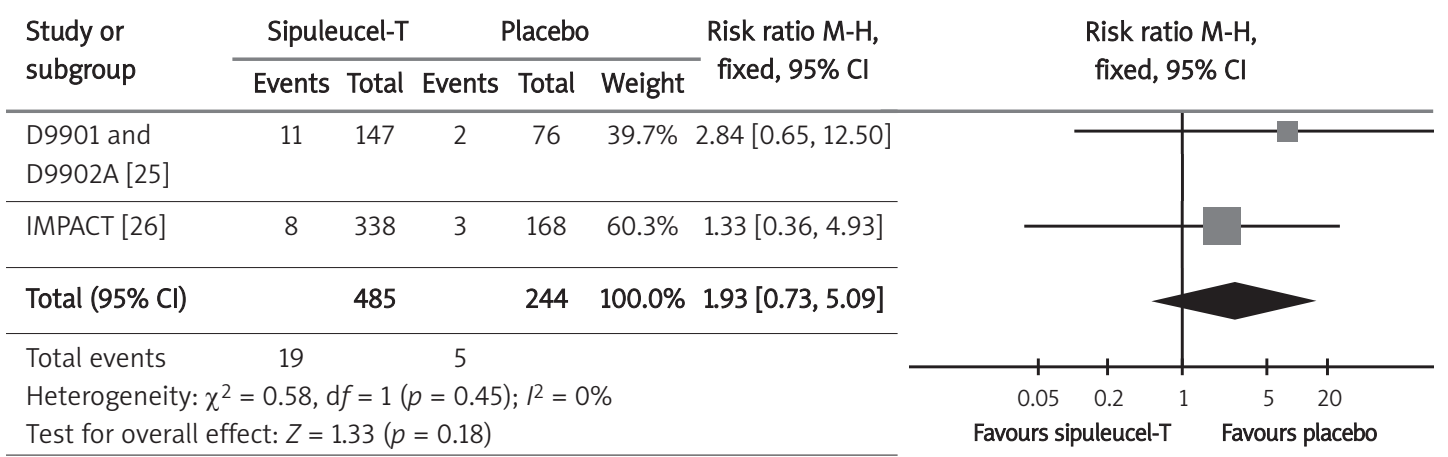

Figure 6. Forest plot representing effects of sipuleucel-T and placebo use on incidence of cerebrovascular events in men with CRPC

$25,26]$ that treatment with the therapeutic cancer vaccine sipuleucel-T led to a significant improvement in overall survival for men with metastatic castration-resistant prostate cancer.

By contrast, the time to disease progression did not differ significantly between treatment arms. This result may be due to the delayed onset of antitumor responses after active immunotherapy, relative to objective disease progression, which occurred early in this group of patients [33]. In patients with metastatic castration-resistant prostate cancer, the disease progression endpoint, as currently defined, is not a reliable predictor of overall survival. Several randomized trials that have shown effects of various treatments on overall survival have not shown the effects on disease progression [34-37], and vice-versa [38], suggesting a possible class effect or some previously unknown feature of prostate cancer.

The preliminary results of the PROTECT (PROvenge Treatment and Early Cancer Treatment) trial, including men with androgen-dependent prostate cancer, have also failed to achieve statistical significance for their primary endpoint, which is biochemical failure (defined as serum PSA level $\geq 3.0 \mathrm{ng} / \mathrm{ml}$ ); however, the survival results are not yet available [39].

Moreover, with the median time to progression of 10-14 weeks, many patients had progressed by the time of the first scan scheduled at 6 or 8 weeks, so that patients may have reached the progression endpoint before achieving the maximal immune response to therapy. As was previously demonstrated, the maximal immune response in some patients may not occur until 12 weeks or longer after the initiation of therapy [40]. Progression may therefore have reflected, in part, what was in progress at the time of enrollment, and not necessarily progression on the therapy. For this reason, the time to progression may not be an appropriate endpoint when testing the effect of immunotherapy in this patient population.
Overall survival may be a more appropriate endpoint for advanced prostate cancer trials, because death events generally occur much later than progression events, allowing more time for the therapy to take effect, particularly for immunotherapeutic agents such as sipuleucel-T.

The mechanisms by which sipuleucel-T provides a clinical benefit are not yet completely understood. However, knowledge of these mechanisms will be crucial for probing human immune responses and tumor biology in order to understand what distinguishes responders from non-responders. The following next steps are necessary: firstly, the development of immune-monitoring strategies for the identification of relevant biomarkers; secondly, the establishment of guidelines for the assessment of clinical endpoints; and thirdly, the evaluation of combination therapy strategies to improve clinical benefit [41, 42].

In conclusion, sipuleucel- $T$ is safe and prolongs survival among men with asymptomatic or minimally symptomatic metastatic castration-resistant prostate cancer. However, no significant effect on the time to objective disease progression was observed.

\section{References}

1. Jemal A, Siegel R, Xu J, Ward E. Cancer statistics, 2010. CA Cancer J Clin 2010; 60: 277-300.

2. Reports from the National Cancer Database according to The Oncology Centre data http://www.onkologia.org. $\mathrm{pl} / \mathrm{pl} / \mathrm{p} / 7 \mathrm{l}$

3. Kozłowska E, Szewczyk MT, Banaszkiewicz Z, Jawień A, Cierzniakowska K, Jarmocik P. Knowledge of symptoms and diagnostic possibilities of cancer diseases. Arch Med Sci 2011; 7: 304-9.

4. Catalona WJ, Smith DS. Cancer recurrence and survival rates after anatomic radical retropubic prostatectomy for prostate cancer: intermediate- term results. J Urol 1998; 160: 2428-34.

5. Eastham JA, Scardino PT. Radical prostatectomy for clinical stage T1 and T2 prostate cancer. In: Comprehensive textbook of genitourinary oncology. Vogelzang NJ, Scardino PT, Shipley WU, Coffey DS (eds). 2nd ed. Lipincott Williams \& Wilkins, Philadelphia 1999. 
6. Walsh PC, Partin AW, Epstein JI. Cancer control and quality of life following anatomical radical retropubic prostatectomy: results at 10 years. J Urol 1994; 152: 1831-6.

7. Clark PE, Levin HS, Kupelian PA, Reddy C, Zippe CD, Klein EA. Intermediate-term outcome with radical prostatectomy for localized prostate cancer: the Cleveland Clinic experience. Prostate J 2001; 3: 118-25.

8. Kantoff PW, Carrol PR, D'Amico AV, eds. Prostate cancer: principles and practice. Lippincott Williams \& Wilkins, Philadelphia 2002.

9. Sharifi N, Gulley JL, Dahut WL. Androgen deprivation therapy for prostate cancer. JAMA 2005; 294: 238-44.

10. Sonpavde G, Di Lorenzo G, Higano CS, et al. The role of sipuleucel-T in therapy for castration-resistant prostate cancer: a critical analysis of the literature. Eur Urol 2012; 61: 639-47.

11. Taxotere $^{\circledR}$ (docetaxel): EPAR - product information http://www.ema.europa.eu/docs/pl PL/document library/EPAR_-_Product_Information/human/000073/ WC500035264.pdf

12. Zaborowska M, Szmit S, Szczylik C. Sorafenib in progressive castrate-resistant prostate cancer. Can we talk about a new therapeutic option? Arch Med Sci 2012; 8: 528-32.

13. Patel PH, Kockler DR. Sipuleucel-T. A vaccine for metastatic, asymptomatic, androgen-independent prostate cancer. Ann Pharmacother 2008; 42: 91-8.

14. http://www.fda.gov/downloads/BiologicsBloodVaccines/ CellularGeneTherapyProducts/ApprovedProducts/UCM213 114.pdf

15. Moher D, Liberati A, Tetzlaff J, et al. The PRISMA Group (2009). Preferred Reporting Items for Systematic Reviews and Meta-Analyses: The PRISMA Statement. PLoS Med 2009; 6: e1000097.

16. Higgins JPT, Green S. Cochrane handbook for systematic reviews of interventions. Cochrane Collaboration and John Wiley 2008.

17. Jadad AR, Moore RA, Carroll D, et al. Assessing the quality of reports of randomized clinical trials: Is blinding necessary? Controlled Clinical Trials 1996; 17: 1-12.

18. Egger M, Davey Smith G, Schneider M, Minder C. Bias in meta-analysis detected by a simple, graphical test. BMJ 1997; 315: 629-34.

19. Review Manager (RevMan) [Computer program]. Version 5.1. Copenhagen: The Nordic Cochrane Centre, The Cochrane Collaboration, 2011.

20. Microsoft Office Exce ${ }^{\circledR} 2007$ [Computer program], Microsoft ${ }^{\circledR}$ Corporation.

21. Small EJ, Schellhammer PF, Higano CS, et al. Placebocontrolled phase III trial of immunologic therapy with sipuleucel-T (APC8015) in patients with metastatic, asymptomatic hormone refractory. J Clin Oncol 2006; 24: 3089-94.

22. Small EJ, Rini B, Higano C, et al. A randomized, placebocontrolled phase III trial of APC8015 in patients with androgen-independent prostate cancer (AiPCa). Proc Am Soc Clin Oncol 2003; 22: 382, Abstract 1534.

23. Schellhammer PF, Small EJ, Higano CS, et al. Autologous dendritic cells pulsed with prostatic acid phosphatase (APC8015) for hormone refractory prostate cancer: a phase III randomized, double-blind, placebo controlled trial. Proc Am Soc Clin Oncol 2002; 21: 183a, Abstract 731.

24. Lee D. Autologous dendritic cells pulsed with prostatic acid phosphatase (APC8015). Clin Prostate Cancer 2003; 2: 81-3.

25. Higano CS, Schellhammer PF, Small EJ, et al. Integrated data from 2 randomized, double-blind, placebo-controlled, phase 3 trials of active cellular immunotherapy with sipuleucel-T in advanced prostate cancer. Cancer 2009; 115: 3670-9.

26. Kantoff PW, Higano CS, Shore ND, et al. Sipuleucel-T immunotherapy for castration-resistant prostate cancer. N Engl J Med 2010; 363: 411-22.

27. George DJ, Vogelzang N, Schellhammer PF, et al. Survival results of the IMPACT trial of sipuleucel-T for advanced prostate cancer. Ann Oncol 2010; 21 (Suppl 8): 272.

28. Kantoff P, Higano CS, Berger ER, et al. Updated survival results of the IMPACT trial of sipuleucel-T for metastatic castration-resistant prostate cancer (CRPC). Genitourinary Cancers Symposium 2010. Oral Abstract Session A: Prostate Cancer.

29. Nabhan C, Gomella LG, DeVries T, et al. An analysis to quantify the overall survival (OS) benefit of sipuleucel-T accounting for the crossover in the control arm of the IMPACT study. J Clin Oncol 2012; 30 (Suppl 5): Abstract 144.

30. George DJ, Nabhan LG, Gomella JB, et al. Subsequent treatment with APC8015F and its effect on survival in the control arm of phase III sipuleucel-t studies. J Clin Oncol 2011; 29 (Suppl 7): Abstract 139.

31. Gomella JB, Nabhan LG, Whitmore JB, et al. Postprogression treatment with APC8015F may have prolonged survival of subjects in the control arm of sipuleucel-T phase III studies. J Clin Oncol 2011; 29 (Suppl): Abstract 4534.

32. Small EJ, Higano CS, Kantoff PW, et al. Time to diseaserelated pain after sipuleucel-T in asymptomatic patients with metastatic castrate resistant prostate cancer (mCRPC): results from 3 randomized phase III trials. Eur J Cancer 2011; 47 (Suppl 1): 484.

33. Draft Guidance for Industry: clinical considerations for therapeutic cancer vaccines. Washington, DC: Department of Health and Human Services, Food and Drug Administration, Center for Biologics Evaluation and Research, 2009. (Accessed February 10, 2012, http://www. fda.gov/BiologicsBloodVaccines/GuidanceComplianceRegu latoryInformation/Guidances/Vaccines/ucm182443.htm.

34. James ND, Caty A, Borre $M$, et al. Safety and efficacy of the specific endothelin- A receptor antagonist ZD4054 in patients with hormone-resistant prostate cancer and bone metastases who were pain free or mildly symptomatic: a double- blind, placebo-controlled, randomised, phase 2 trial. Eur Urol 2009; 55: 1112-23.

35. Kantoff PW, Schuetz TJ, Blumenstein BA, et al. Overall survival analysis of a phase II randomized controlled trial of a Poxviral-based PSA-targeted immunotherapy in metastatic castration-resistant prostate cancer. J Clin Oncol 2010; 28: 1099-105.

36. James ND, Borre M, Zonnenberg BA, et al. ZD4054, a potent, specific endothelin $A$ receptor antagonist, improves overall survival in pain-free or mildly symptomatic patients with hormone-resistant prostate cancer (HRPC) and bone metastases. EJC Supplements 2007; $5: 3$.

37. Kantoff PW, Glode LM, Tannenbaum SI, Billhartz DL, Pitman WG, Schuetz TJ. Randomized, double-blind, vectorcontrolled study of targeted immunotherapy in patients with hormone-refractory prostate cancer. J Clin Oncol ASCO Annu Mtg Proc 2006; 24: 2501.

38. Sternberg CN, Petrylak DP, Sartor O, et al. Multinational, double-blind, phase III study of prednisone and either satraplatin or placebo in patients with castrate-refractory prostate cancer progressing after prior chemotherapy: the SPARC trial. J Clin Oncol 2009; 27: 5431-8. 
39. Beer TM, Bernstein GT, Corman JM, et al. Randomized trial of autologous cellular immunotherapy with sipuleucel-T in androgen-dependent prostate cancer. Clin Cancer Res 2011; 17: 4558-67.

40. Small EJ, Fratesi P, Reese DM, et al. Immunotherapy of hormone-refractory prostate cancer with antigenloaded dendritic cells. J Clin Oncol 2000; 18: 3894-903.

41. Sharma P, Wagner K, Wolchok JD, Allison JP. Novel cancer immunotherapy agents with survival benefit: recent successes and next steps. Nat Rev Cancer 2011; 11: 805-12.

42. Madan RA, Gulley JL, Fojo T, Dahut WL. Therapeutic cancer vaccines in prostate cancer: the paradox of improved survival without changes in time to progression. Oncologist 2010; 15: 969-75. 